\title{
Early Postoperative Complications in Primary Cleft Lip and Palate Repair: A Retrospective Analysis of 328 Cases
}

\section{Dudak Damak Yarıklarının Primer Onarımında Erken Postoperatif Komplikasyonlar: 328 Olgunun Retrospektif Analizi}

\author{
Mustafa Sütçü1', Cemil Işık1, Ahmet Rıfat Doğramacı', ®Celal Irgın³, Osman Akdağ1, \\ DZekeriya Tosun'
}

\author{
'Selcuk University, Faculty of Medicine, Department of Plastic and Reconstructive Surgery, Konya, Turkey \\ ${ }^{2}$ Erciyes University, Faculty of Dentistry, Department of Orthodontics, Kayseri, Turkey
}

\begin{abstract}
Aim: Primary cleft lip and palate (CLP) repair is the most critical stage throughout lifetime. CLP surgery involves risks of surgery and anesthesia related complications. In this study, it was aimed to evaluate the complications occur in the early period after primary CLP surgery and to determine early factors that trigger these conditions.

Material and Method: In this study 328 surgeries of 271 CLP patients were included. Complications such as fever occurring in the first 3 days were classified as minor complications. Complications that could not be treated with palliative care or that had to be transferred to intensive care were considered as major complications. The epidemiology and causal link of early complications were statistically evaluated.

Results: Early complications were seen in 19\% (n:63) of all cases that were operated for cleft lip and palate. Among them, rate of minor complications was $9 \%$ (n: 25$)$. It was determined that prolongation of anesthesia caused an increase in minor complications such as inadequate oral nutrition. Major complications were observed in $11 \%$ (n: 38). These major complications were more common in patients with bilateral cleft lip, cleft palate, syndromic cases, and male patients. Complicated cases' mean length of stay in hospital was 3.35 days. When compared with noncomplicated cases, there was increase in hospitalization time $(p<0.05)$.

Conclusion: Minor complications can be prevented with careful intubation and shortening the surgery duration. Despite all these precautions, major complications are still very important problems in bilateral cleft lip, syndromic and male patients. Therefore, it is mandatory to perform these surgeries in centres where management of these complications is possible.
\end{abstract}

Keywords: Cleft lip and palate, early, postoperative, complications
Öz

Amaç: Primer dudak damak yarığı (DDY) onarımı, yaşam boyu en kritik aşamadır. DDY ameliyatı, ameliyata ve anesteziye bağlı komplikasyon risklerini içerir. Bu çalışmada, primer DDY cerrahisi sonrası erken dönemde meydana gelen komplikasyonların değerlendirilmesi ve bu durumları tetikleyen erken dönemdeki faktörlerin belirlenmesi amaçlanmıştır.

Gereç ve Yöntem: Bu çalışmaya 271 DDY hastasının 328 ameliyat dahil edildi. Illk 3 günde ortaya çıkan ateş gibi komplikasyonlar minör komplikasyon olarak sınıflandırıldı. Palyatif bakımla tedavi edilemeyen veya yoğun bakıma transfer edilmesi gereken komplikasyonlar ise majör komplikasyonlar olarak kabul edildi. Erken komplikasyonların epidemiyolojisi ve nedensel bağlantısı istatistiksel olarak değerlendirildi.

Bulgular: Dudak damak yarığı nedeniyle ameliyat edilen tüm olguların \%19'unda (n: 63) erken komplikasyonlar görüldü. Bunlar arasında minör komplikasyon oranı \%9 (n: 25) idi. Anestezinin uzamasının ağızdan beslenmede yetersizlik gibi minör komplikasyonların artmasına neden olduğu belirlendi. Majör komplikasyonlar \%11 (n: 38) oranında görüldü. Bu majör komplikasyonlar, bilateral dudak yarığı olanlarda, sendromik olgularda, damak yarığı olanlarda ve erkek hastalarda daha sıktı. Komplike vakaların ortalama hastanede kalış süresi 3,35 gündü. Komplike olmayan vakalarla karşılaştırıldığında hastanede kalış süresinde artış vardı $(p<0,05)$.

Sonuç: Dikkatli entübasyon ile anestezi ve ameliyat süresinin kısaltılması minör komplikasyonları önleyebilir. Tüm bu önlemlere rağmen iki taraflı dudak yarıklarında, sendromlu hastalarda ve erkek hastalarda majör komplikasyonlar hala çok önemli problemlerdir Bu nedenle bu komplikasyonların yönetiminin mümkün olduğu merkezlerde dudak damak yarığı ameliyatlarının yapılması zorunludur.

Anahtar Kelimeler: Dudak damak yarı̆̆ı, erken, postoperatif komplikasyonlar 


\section{INTRODUCTION}

Cleft lip and palate patients need many operations throughout their lives. In this patient group, complications related to surgical procedures can be seen, as well as different complications that may threaten patient's life in early postoperative period. Primary operations in cleft lip and palate make risks of general anaesthesia more pronounced than surgery procedure risks due to it's being done in infantile period. It is known that anesthesia risks are higher in early childhood and especially in newborns. ${ }^{[1]}$ At the same time risk of general anesthesia is higher in patients with cleft lip and palate compared to normal patient population. ${ }^{[2]}$ Moreover, many additional anomalies and syndromes may accompany cleft lip and palate. ${ }^{[3]}$ This increases the complication rate during and after the operation. Management of the early complications has to be done by plastic surgeons.

In this study, early complications after primary cleft lip and palate repair in children were investigated retrospectively. It is aimed to determine factors that cause complications in primary cleft lip and palate surgery (first surgery) that involve surgery and anesthesia related complications risks together. Preventive measures are discussed in the light of the literature.

\section{MATERIAL AND METHOD}

A total of 328 surgeries of 271 cases with cleft lip or palate between January 2012 and October 2018 were retrospectively analyzed. Data were obtained from ENLiL ${ }^{\circledR}$ hospital information management system and anesthesia course form. The study was approved by the Ethics Committee of the Selcuk University Faculty of Medicine (no: 2018/23) and performed in accordance with the Declaration of Helsinki and protection of personal data.

All surgeries were performed under elective conditions and were preoperatively consulted with an anaesthesiologist and a paediatrics physician. Complications seen in first three days from the day of the operation were included in the study. Patients over 2 years old were excluded. Ages, weights of the patients and duration of anesthesia were recorded from hospital data system. Type of the deformity was classified as bilateral and unilateral for the cleft lip and as complete and incomplete for the cleft palate.

Postoperative fever, mechanical airway destruction, respiratory tract infection, ischemia / dehiscence in flap and bleeding were recorded. Complications such as fever that was treated with simple methods, partial wound separation, temporary hypothermia and hospitalization period less than two days were classified as minor complications. Respiratory tract infection, airway destruction, excessive postoperative bleeding and complete wound dehiscence or patients with hospitalization period longer than 2 days or requirement to transfer to intensive care unit, were defined as major complications. ${ }^{[4]}$

Relationship between all complications and gender, weight, cleft type, duration of anesthesia, duration of hospitalization and additional anomalies were statistically evaluated. Chisquare and t test were used for evaluation and a value of $p<0.05$ was considered significant for all analyses. SPSS ${ }^{\circledR}$ statistics program was used for statistical analysis (version 21.0 for Windows; Armonk, NY: IBM Corp.)

\section{RESULTS}

Patients' age ranged from 4 months to 24 months (mean: 11.19 months). It was observed that 76\% (n: 95) of cleft lip patients had unilateral lip deformity. Bilateral cleft lip percentage was 24\% (n: 30). Complete cleft palate deformity was observed in $52.2 \%$ ( $n: 106)$ of the patients and incomplete deformity was seen in $47.8 \%$ (n: 97 ) of the patients. Early complications were detected in $19 \%$ of the primary 328 operations (n: 63). While $11 \%$ ( $\mathrm{n}$ : 38 ) of all complications were major complications, $8 \%$ (n: 25) percent of complications were minor complications (Graphic 1). The most common major complications were respiratory tract infection (n: 10) and airway destruction (n: 10) in primary palate repair patients. Ratio of treatment requiring respiratory infection was determined as $4.27 \%$. Severe bleeding requiring transfusion was detected in only one patient after primary palate repair. Both major complications and minor complications were more common in male cases than in female and it was a statistically significant difference (Graphic 2). Early complications were found to be higher in patients with cleft palate compared to primary lip repair patients $(p<0.05)$. More major complications were observed in patients with bilateral cleft lip than unilateral cleft lip patients. The difference was statistically significant $(p<0.05)$ (Graphic 3).

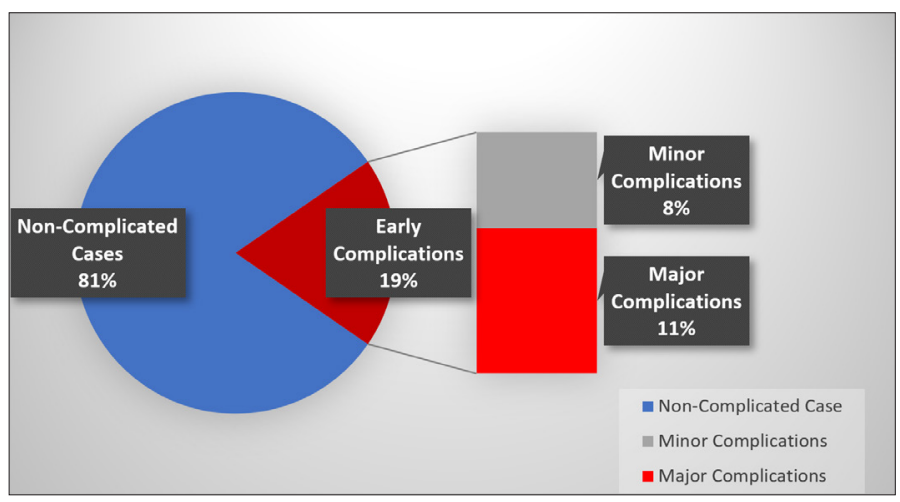

Graphic 1. Early complication rate

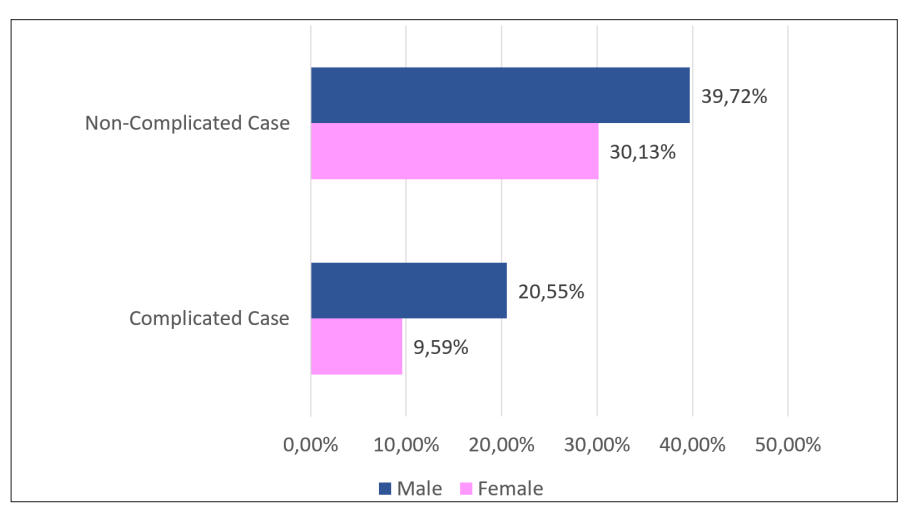

Graphic 2. Patient Distribution Rate by Gender 


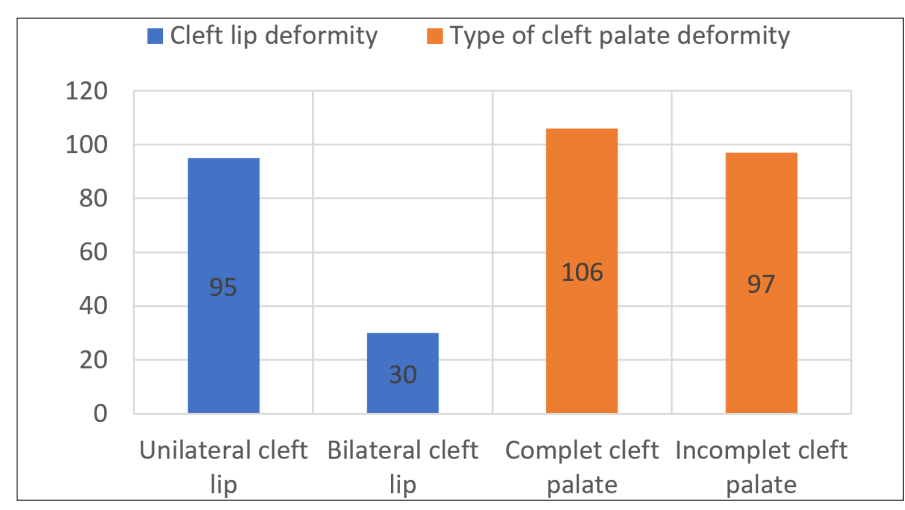

Graphic 3. Early Complication Numbers

In patients without any complications, mean anesthesia duration was 124 minutes. On the other hand, average anesthesia duration was observed as 134 minutes in palate repair surgeries with major complications. There was no statistically significant difference in duration of anesthesia with major complicated and non-complicated palate repair patients ( $p>0.05$ ). However, it was observed that duration of anesthesia was significantly effective in development of minor complications (p: 0.039).

In major complications with cleft lip patients, anesthesia duration was not an effective factor ( $p>0.05)$. Similar to palate repair patients, general anesthesia time was an efficient factor in the development of minor complications ( $p: 0.047$ ).

Although mean weight of complicated cleft lip patients was lower than uncomplicated cases, no statistical difference was observed $(p>0.05)$. As low weights were similarly observed in complicated cleft palate patients (Table 1), there was no statistically significant difference $(p>0.05)$. Major complications were significantly increased in patients with additional anomalies or syndromes $(p<0.05)$. Cardiac anomaly was present in $65 \%$ of the patients who developed major complications (Table 2).

\section{Table 1. Average weights by deformity}

\begin{tabular}{lc}
\hline Deformity & $\begin{array}{c}\text { Mean weight }( \pm \text { SD) } \\
\text { (Min. }- \text { Max. weight) }\end{array}$ \\
\hline Complicated cleft lip & $6743.31 \mathrm{~g}( \pm 1762.25)$ \\
Non-Complicated cleft lip & $7131.62 \mathrm{~g}( \pm 1133.59)$ \\
Complicated cleft palate & $8462.74 \mathrm{~g}( \pm 1353.90)$ \\
Non-Complicated cleft palate & $9513.88 \mathrm{~g}( \pm 1880.10)$ \\
\hline SD: Standart deviation &
\end{tabular}

Table 2. Distribution of additional anomaly or syndrome

\begin{tabular}{lc} 
Additional Anomaly or Syndrome & Number of Patients \\
\hline Cardiac anomaly & 11 \\
Down syndrome & 3 \\
Other syndromes & 4 \\
Microcephalia & 3 \\
Laryngomalacia & 1 \\
Renal agenesis & 1 \\
Asthma & 1 \\
Status epilepticus & 1 \\
History of intensive care units & 5 \\
\hline
\end{tabular}

Mean length of hospital stay was 1.27 days in cleft palate patients without complications, and 1.67 days in non-complicated cleft palate patients. The duration of hospitalization was 3.17 days and 3.54 days, respectively in cleft lip and palate patients that complications occurred. It was found that complication development significantly increased the duration of hospitalization $(p<0.05)$.

\section{DISCUSSION}

Many organs are immature in early years of life. This situation causes a predisposition to complications during surgery. [5] Although most of these early complications are related to anesthesia, they are also important for plastic surgery practice. Early diagnosis and treatment are critical. Moreover, it is urgent to identify complications in this group of patients who are often discharged on the first postoperative day. ${ }^{[6]}$ There are factors affecting early postoperative complications in all three periods including preoperative evaluation, during anesthesia and postoperative care.

Continuous contact of the nasal cavity with food and saliva causes frequent upper respiratory infections in children with cleft lip and palate. ${ }^{[7]}$ Presence of infection in any part of respiratory system triggers anesthesia related complications. [1] At the same time, nutritional deficiency, micrognathia, macroglossia and glossoptosis cause an increased risk for general anesthesia. Many centres reported different postoperative complication rates ranging from $3 \%$ to $38 \%$. ${ }^{[3,8-12]}$ This situation is mostly related to classification system of complications and diagnostic methods. Early postoperative complications can be classified as two parts as major lifethreatening complications that require advanced treatments, and minor complications that can be eliminated with palliative treatments such as fluid replacement and antipyretic therapy. [4]

Complications have been reported to be associated with age in literature. Therefore, the most important factors that determine the operation timing are the weights and ages of the children's. Even in the 'Rule of 10s' proposed by Wilhelmsen and Musgrave, the two main rules that determine the timing of the surgery are the weights and ages of the patients. ${ }^{[13]}$ Nowadays, patients in young age and low weight in weight in parallel to the development of anesthesia techniques can be operated safely. Nevertheless, in the current literature has been shown to be no significant difference between the effects of the ages of the patients to the overall complication rates. ${ }^{[1,14]}$ Similarly, in our study, there was no relationship between the development of early complications and age and weight. ${ }^{[9,15]}$

In literature, it was shown that cleft lip and palate can be associated with more than 150 syndromes or anomalies. ${ }^{[11]}$ For this reason, some preliminary evaluations are made for prevention of complications. Especially for patients with additional anomalies or syndromes, preoperative evaluations are more valuable because of high rate of complications. As a 
result of our study, general anesthesia increases complication rates in patients who have cardiac anomalies and these complications tend to be serious. It has been suggested in the literature that cases with cardiac problems should be operated in the late periods of life to reduce the negative effects of complications. ${ }^{[16]}$ Similarly, increased rate of complications are also observed due to additional anomalies in male patients and bilateral cleft patients.

To prevent early postoperative respiratory complications; diagnosing viral upper respiratory tract infections, questioning vaccination, and bleeding disorders history are essential and postponing the surgery when necessary is the most important measure. ${ }^{[1]}$ Otolaryngology consultation may be required for asymptomatic serous otitis media and possible ventilation tube applications.

Anatomical variability of the upper airways of cleft lip and palate patients causes intubation difficulties. ${ }^{[12]}$ It has been shown that respiratory problems may be related to recurrent intubation trials. Especially in this group of patients; false intubation, difficultintubation, tubeseparation orcompression, desaturation, laryngeal spasm, and bronchospasm have been reported frequently. ${ }^{[12]}$ In order to prevent breathing problems, reinforced cuff-free ventilation tubes should be used, gentle intubation should be performed, and irritation should be avoided. Another issue to be considered in early years of life is the amount of intravascular fluid. While body weight is between $5 \mathrm{~kg}$ and $10 \mathrm{~kg}$, total blood volume is $400-700 \mathrm{ml}$. Therefore, even small volume blood losses or dehydration can result in hemodynamic disorders. Intraoral surgery creates intubation and laryngoscopy difficulties. Significantly major complications are higher in palate repairs than lip repairs. In the literature, this situation is associated with the amount of blood loss. ${ }^{[11]}$ In the literature, meticulous surgery performed in experienced hands, has been shown to be especially related to low bleeding rates. ${ }^{[15]}$

Our study shows that prolonged operation time has negative effects on palate cleft repair, especially for major complications. However, we think that this situation is mostly related to already difficult cases or intubation problems (difficult intubation, separation of the tube, pressing the tube ...) caused to long surgery time.

In the postoperative period, airway irritation can be reduced with cold steam. Routine body temperature measurement during and after surgery are also important and measurement being $38^{\circ} \mathrm{C}$ and above is an indicators for early intervention to prevent complications. Insufficient analgesia or reflux after starting feeding too early may result in apnea as a result of vagal stimulation. ${ }^{[17]}$ At the same time, parents' reservations about feeding may cause inadequate fluid intake too. Therefore, education of parents and nurses about nutrition is effective in correcting this situation.

Fillies et al. ${ }^{[11]}$ suggested that early complications were more common in children between 4000-6000 gr. However, it was demonstrated with this study that weight was not associated with the triggering of early complications due to the fact that primary surgery was not performed under 6000 gr. in our clinic. Therefore, performing the surgery at the appropriate weight will not increase major complications in cleft lip and palate surgeries.

\section{CONCLUSION}

Most similar retrospective studies show that complications seen in primary surgeries of patients with cleft lip and palate have decreased over the years. With data of non-profit medical organisations such as Operation Smile, in which a large number of cleft lip and palate surgeries are performed, it has been shown that there is a decrease in many early complications with the above mentioned prevention measures. ${ }^{[15]}$

The development of minor complications can only be prevented by taking history, doing a physical examination, performing surgery at appropriate weight and shortening the general anesthesia duration. Significant parts of the minor complications that cause prolongation in hospital stay can be prevented with routine, strict measures. However, major complications remain as an important problem for in bilateral cases, patients with anomaly or syndrome, and male patients with cleft palate. Extended operative time is also a significant problem. In central hospitals, experienced surgical team with the appropriate equipment will reduce the morbidity by facilitating the treatment of major complications that may develop.

\section{ETHICAL DECLARATIONS}

Ethics Committee Approval: Selcuk University Faculty of Medicine Non-Interventional Clinical Research Ethics Committee (Date: 17.01.2018, Number: 2018/23)

Informed Consent: Because the study was designed retrospectively, no written informed consent form was obtained from patients.

Referee Evaluation Process: Externally peer-reviewed.

Conflict of Interest Statement: The author(s) declared no potential conflicts of interest with respect to the research, authorship, and/or publication of this article.

Financial Disclosure: The authors declared that this study has received no financial support.

Author Contributions: All of the authors declare that they have all participated in the design, execution, and analysis of the paper, and that they have approved the final version.

\section{REFERENCES}

1. Takemura H, Yasumoto K, Toi T, Hosoyamada A. Correlation of cleft type with incidence of perioperative respiratory complications in infants with cleft lip and palate. Paediatr Anaesth. 2002;12(7):585-8.

2. Tiret L, Nivoche Y, Hatton F, Desmonts JM, Vourc'h G. Complications related to anaesthesia in infants and children. A prospective survey of 40240 anaesthetics. Br J Anaesth. 1988;61(3):263-9. 
3. Druschel CM, Hughes JP, Olsen CL. First year-of-life mortality among infants with oral clefts: New York State, 1983-1990. Cleft Palate Craniofac J. 1996;33(5):400-5.

4. Cohen MM, Cameron CB, Duncan PG. Pediatric anesthesia morbidity and mortality in the perioperative period. Anesth Analg. 1990;70(2):160-7.

5. Denk MJ, Magee WP Jr. Cleft palate closure in the neonate: preliminary report. Cleft Palate Craniofac J. 1996;33(1):57-66.

6. Cronin ED, Williams JL, Shayani P, Roesel JF. Short stay after cleft palate surgery. Plast Reconstr Surg. 2001;108(4):838-41.

7. Jaffe, B.F. and C.B. DeBlanc, Sinusitis in children with cleft lip and palate. Arch Otolaryngol, 1971; 93(5):479-82.

8. Deshpande GS, Campbell A, Jagtap R, et al. Early complications after cleft palate repair: a multivariate statistical analysis of 709 patients. J Craniofac Surg. 2014;25(5):1614-8.

9. Schönmeyr B, Wendby L, Campbell A. Early Surgical Complications After Primary Cleft Lip Repair: A Report of 3108 Consecutive Cases. Cleft Palate Craniofac J. 2015;52(6):706-10.

10. Tiret L, Desmonts JM, Hatton F, Vourc'h G. Complications associated with anaesthesia--a prospective survey in France. Can Anaesth Soc J 1986;33(3 Pt 1):336-44.

11. Fillies T, Homann C, Meyer U, Reich A, Joos U, Werkmeister R. Perioperative complications in infant cleft repair. Head Face Med. 2007;3:9.

12. Desalu I, Adeyemo W, Akintimoye M, Adepoju A. Airway and respiratory complications in children undergoing cleft lip and palate repair. Ghana Med J. 2010;44(1):16-20.

13. Wilhelmsen HR, Musgrave RH. Complications of cleft lip surgery. Cleft Palate J. 1966;Jul;3:223-231.

14. Chow I, Purnell CA, Hanwright PJ, Gosain AK. Evaluating the Rule of 10s in Cleft Lip Repair: Do Data Support Dogma?. Plast Reconstr Surg. 2016;138(3):670-9.

15. Park E, Deshpande G, Schonmeyr B, Restrepo C, Campbell A. Improved early cleft lip and palate complications at a Surgery Specialty Center in the Developing World. Cleft Palate Craniofac J. 2018;55(8):1145-52.

16. Ramamoorthy C, Haberkern CM, Bhananker SM, et al. Anesthesiarelated cardiac arrest in children with heart disease: data from the Pediatric Perioperative Cardiac Arrest (POCA) registry. Anesth Analg. 2010;110(5):1376-82.

17. DeMey A, Vadoud-Seyedi J, Demol F, Govaerts M. Early postoperative complications in primary cleft lip and palate surgery. Eur J Plast Surg 1997;20(2):77-9. 